\title{
Autonomous Learning in Tertiary University EFL Teaching and Learning of the People's Republic of China
}

\author{
Jinjin $\mathrm{Lu}$
}

\begin{abstract}
English language, as a vital foreign language, has received considerable attention in the last 25 years in education in the People's Republic of China. Moreover, with the development of second language acquisition theories in these years, more theories and ideologies have been introduced into China. Autonomous learning is an important case in point. When the idea of 'autonomous learning ' was brought into EFL teaching and learning at the beginning of the 1990s, some Chinese scholars accepted the concept without any critical thought of its application in a Chinese context, which results in an increasing blurring of its boundaries. This paper firstly gives an overview of the development of autonomous learning in the PRC, and then secondly moves to present the model of English language learning and teaching by using autonomous learning theory within the Chinese context., Finally it utilizes information that leads to the suggestions and recommendations to university staff, students and SAC managers in the PRC.
\end{abstract}

Index Terms-Autonomous learning, EFL teaching and learning, SLA theory, chinese context, SAC.

\section{INTRODUCTION}

Learning autonomy is an innovative concept which was introduced into China in the 1990s. The definition of autonomy was imported originally from the fields of politics and moral philosophy and it is a multifaceted concept whose meaning has been discussed in an increasingly academic fashion. Briefly, learner autonomy was defined by Henri Holec and his colleagues in a European language project in 1970 [13]. One of the outcomes of this project was the establishment of the Centre de Recherches et d'Applications Pédagogiques en Langues at the University of Nancy, France (CRAPEL). In 1976, a seminar report published by Holec, was regarded as an important foundation in the field of autonomy. The report was on self-directed learning and autonomy, which was made contributions by Holec and his colleagues. Also, the journal Mélanges Pédagogiques has played an important role within the field of autonomy from 1970 to the present. Many early important works from this period could be found in the journal of Mélanges Pédagogiques and in papers presented at the University of Cambridge [12]. In order to promote lifelong learning, adults were offered the opportunity at CRAPEL to learn a foreign language in a resources centre, free from teacher direction. However, this practical application focused on self-directed learning proved that participants did not have the full competence to take charge of decision-making in all the areas

Manuscript received June 9, 2012; revised August 3, 2012

Jinjin Lu is with the faculty of Education, University of Tasmania, Australia. (e-mail: helen820919@sina.com). normally determined by an institution, teacher, or textbook. Consequently various kinds of support measures were put into the development of learners' abilities to work more effectively in a self-directed fashion by CRAPEL [11]. This experiment connected education, individual freedom and social responsibility, which reflected the views of personal autonomy prevailing in Europe and America at that time.

Generally speaking, early ideal practice of learning autonomy was focus on 'total independent learning' [13], [15] which means learners should be responsible for the whole decision-making process of their learning. During this process, learning autonomy was regarded as 'a rejection of the traditional classroom and the introduction of wholly new ways of working"' [1]. According to Allwright's ideas, most participants in early experiments were adults who did not have chances to attend classroom-based courses. However, Allwright claimed that if autonomy was applied into the classroom, it needed to be re-conceptualized [9]. Later, Dickinson [13] also argued learners often behaved independently in the classroom. Thus, with Dam's demonstration of autonomy, in which principles could be integrated into classrooms. A shift to classroom applications was a second wave of autonomy interest in the 1990s [11]. In this period, scholars put emphasis on the theoretical implications of the pedagogical research [5]- [7]. Meanwhile, large quantities of self-access learning centers were set up after the 1990s, which further put Allwright's pedagogy into a reality that language teachers could come to terms with [8]. Thus, with the influence of the deconstruction of the conventional classroom, many researchers come to the third wave of interest in learner autonomy,, which leads to a tendency of exploring and understanding the role of autonomy in language teaching and learning [2]- [4].

\section{The DEVELOPMENT OF AutONOMOUS LEARNING IN CHINA}

Although learning autonomy is an ideology from the Western world when it was first introduced and applied into Chinese EFL classes, Chinese researchers showed great enthusiasm for it. Liu [14], as the first Chinese scholar to be involved in this field, illustrated developing learning autonomy as a process of facilitating life-long learning. It was explored in four aspects, namely: the definition of self-directed learning, the learners' identification, the learning theory and the practice on the development of self-directed learning. This paper was regarded as the first one which advocated self-access learning in mainland China [11]. Afterwards, Li explained the importance of cultivating communicative competence in intercultural environment in a 
Chinese context [9]- [10]and based his discussions on the previous reviews of Allwright, Walther, Wood and Smith, and Gao [1]-[10]focused on the extent of the freedom learners can have in the Chinese context and what the important factors were that impacts on the development of learning autonomy in Chinese universities. Also, it was suggested that Self-Access Centers (SAC) should be set up in universities since it was essential for improving language learning in China. In the $21 \mathrm{st}$ century, the trend of discussions of learning autonomy was shifting from the simple introduction of concepts to some empirical experiments although they were on a small scale. What is more, the focus has been shifted from the theory to the practice. The most important improvement is to stress changing teachers' roles in the SAC in EFL learning and teaching.

\section{Changes of EFl Teaching Model In the SAC}

The English teaching model was described as "teachers-centered" in the past 25 years of China because of the Chinese cultural influence. With the ideology and value of Confucian thinking, education was perceived as being reliant upon authority in the classroom. Therefore, the way in which most students showed respect to the teachers was to attend classes on time and listen to the lectures quietly. The students showed a high degree of respect to their teachers. In the class, the teachers imparted knowledge to the students passively. In some cases; students could ask questions after class. Hence, the relationship between teachers and students were more like "Fu and zi", that is, "father and son". In these perceptions, the traditional Chinese model of teaching was regarded as one of "empty-vessel" or a "pint pot" [7]. The detail of this model is shown in figure1.

Traditionally, the EFL teaching methods utilized in China were mainly of expository and the teaching process was dominated by teachers [13]. The teacher selected important grammatical points from the original English books or articles to interpret analyze and drill these grammar points in and after the English class. It was seen as the most effective EFL teaching method to help students connect the new knowledge with the old one. The process of knowledge transmission at that time was directly from teachers to students and its delivery was carefully sequenced for students to memorize, repeat and understand. The teaching materials were focused on printed English textbooks, which were also mainly focused on the grammar drills.

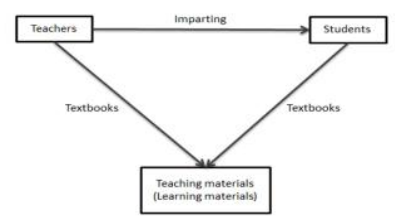

Fig. 1. Traditional EFL teaching model in class.

Based on the principles and the guidance of the CECR, the first self-access language learning center was set up in Chongqing University in 2005 in the People's Republic of China. The language learning center of Chongqing University (LLCCU) was open to $20 \%$ of total university students at campus in 2004 to run learning and teaching trial.
The Ministry of Education emphasized that a computer-based learning system should be applied to college and university English courses, particularly; a self-access center should be regarded as a medium to improve students' oral English and listening skills. At this stage, facilitating students' English communicative competence was the initial purpose in the self-access learning center rather than enhancing students' autonomous capacity. In 2005, due to the perceived success of the introductory trial in the first- year of teaching and learning in the SAC, all the students had access to the self-access learning centers at campus in the following year. Compared with the facilities used in 2004, a wide range of online English courses in the language learning center were developed to meet students and staff's needs. This included the, College English course online system, Intensive English online course system and English online resource system. Moreover, some language software, such as New Horizon English online software and Moodle were installed in the language center computers for students.

From 2006 to 2009, the Self-access Centre developed fast and it provided 4000 different types of video resources and more than 1000 visual -video resources. Meanwhile, online English course evaluation systems and online self-evaluation systems were purchased with school funds, enabling systems access to take part in university exams for students. With the development of the advanced technology and new requirements of English course reform in 2009, the teaching model utilized in the English class experienced considerable changes based on SAC. The traditional 'teacher-directed' class has been shifted to a 'student-directed' model, that is, the model is defined as ' $2+2+X$ '. The first ' 2 ' refers to the average time students should spend in the self-access center on learning English based on the online learning materials and on the pre-assignments set online by the academic staff. In these two hours, the English teachers and the lab managers need a cooperation to help students to deal with their questions in both English and computer technical skills. The second ' 2 ' means students who have studied in the self-access center need to attend a two-hour lecture per week. This form was adopted by a face to face lecture, that is, academic staff explained and guided students to explore further learning in English based on the questions students met in self-access learning center in the first 2 hours. The last ' $\mathrm{X}$ ' stands for using online learning system in regard to unlimited place and time. Students can choose to learn in the self-access centers or other places where can access the campus wireless Internet. Meanwhile, seminars and workshops are also provided if students need. This model is presented in figure 2 in detail.

\section{SugGeStions And ReCOMmENDATIONS}

This paper provides an overview of the substantial improvements in learning autonomy in EFL in the People's Republic of China over the past 25 years. There is no doubt that the Ministry of Education regarded enhancing the learners' autonomous capacity as important in the $21 \mathrm{st}$ century. However, despite impressive progress has been achieved in the development of teaching methods, teaching and learning materials and teaching models, a host of issues 
deserve attention and careful deliberation. [8] Cooperation between academic staff, students, and SAC managers are essential since SAC can bridge the relationship between the staff and the students. Also, training is proposed to be provided to both the academic staff and students to change their roles from 'teacher-centered' to 'student-centered' in English classes. There is also a need for discussion on solving some technological problems in the online learning systems when students study on and outside campus. The following discussions and recommendations will be focused on three main issues mentioned in the EFL learning and teaching process based on the adoption of the SAC.

A. Cooperation between Academic Staff, Students, and SAC Managers

The cooperation between the English teachers, students and SAC managers plays an important role in enhancing students' learning autonomy. Just like Gardner claims the SAC manager has several roles in being involved in the center, such as working well with teachers and senior managers, providing supportive materials to learners and teachers, and building up an effective learning environment [12]. Similarly, Morrison suggests that the over-riding goal of the SAC manager is to support independent learning to learners and to provide learning resources and services to meet their individual needs . However, in tertiary universities in the PRC, the role of the SAC managers is almost always taken by laboratory technicians since there are not financial available to run a separate position for them respectively. However, most laboratory technicians are unable to make effective learning plans and provide students with updated learning resources since they lack specific knowledge in English language pedagogy. From this point, the SAC manager is regarded as a key position in enhancing learners' autonomy in the SAC.

\section{B. Training Provided to Students and Academic Staff in the SAC}

As we understand that teaching is highly valued in China and collective-oriented morals are rooted in Chinese students and families, it is better to provide support for those students who have not previously been encouraged to learning independently, as well as for new academic staff who are not experienced in a SAC (Gardner, 2011). It is suggested that the orientation program should be available to students, which further provides students with guidance to access to learning resources and helps them to set goals. Moreover, helping students to choose the most appropriate online learning sites also needs consideration. Currently, some students feel threatened to be involved in the SAC because most computer-based learning activities leave students to struggle alone (Barnett, 1993). Facing autonomy, Chinese students cannot adapt to the way in which the high technology transfers the classroom methods used onto the online learning system. Barnett [5] suggests that assisting learners to access the websites and the activities online in order to help them avoid learning aimlessly. Therefore, it is proposed the orientation program "need to be augmented by an introductory and help page" [3].

Staffs are also needed to be trained to: understand the goal of self-access, prepare appropriate learning and teaching materials, manage the students in the SAC with the SAC managers and become a learning advisor to solve out students' problems. In most Chinese Normal universities, teaching and training for novice teachers are conducted in classroom teaching; thus, this kind of group teaching methods make it difficult for some new teachers to leave behind the concept of discipline and controlling students when they enter into the SAC. A focus of training at this moment must be to help those new staff shift "the locus of control to the learner and incorporate choice and opportunities for the reflection in materials and activities" [15].

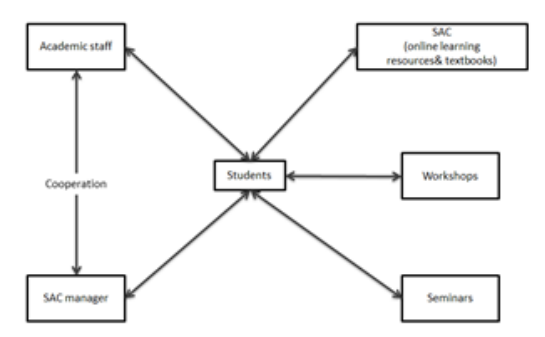

Fig. 2. EFL teaching model in the SAC.

\section{Tackling Technological Problems in the Online Learning Systems}

With the development of high technology, traditional paper teaching and learning materials are replaced by the electronic learning materials for leaners in the SAC. It is a positive trend for learners and staff since students can benefit from it without the limitation of location and time of their learning. Learners can decide and monitor their learning process on campus by themselves. Also, with an online learning system, academic staff and students are likely to find it easier to interact with each other regularly, which can impart understanding of students' problems and help them with their learning. Godwin-Jones states that some emerging technologies, such as online blogs, Google Docs., and an electronic portfolio, are becoming the effective means for students to enhance learning autonomy in a SAC [9]. Online blogs are similar to "logbooks" which were traditional methods to help not only learners develop metacognitive knowledge but also staffs have reflective thinking in a diary. Google Document is used as documents shared by teachers and peers. E-portfolios are another method utilized to record achievements and learning trajectories in rich fields.

However, the issues of technological problems are raised by students and academic staff in most Chinese universities of mainland China. Due to a lack of Internet access to YouTube, Facebook and other popular communicative tools in other countries, Chinese students feel it is difficult to contact with other English teachers or to search for learning resources from the websites from other countries when they need help. Moreover, the only teaching resources academic staff could access at this moment in the online system are New Horizon English Online System, which was developed by the Shanghai Foreign Institute. The New Horizon English Online System is a commercial product purchased by the universities to install in every SAC to integrate the self-access learning into classroom learning environment Thus, an urgency to tackle the technical problems is the most 
important part in developing learning autonomy; otherwise, entailing teaching and learning material to individual learners, changing teachers' roles, providing trainings for students and staff seems a complex process.

\section{CONCLUSION}

There have clearly significant improvements of English language teaching and learning made by MOE in the People's Republic of China in last two decades, in particular, in regard to the self-access learning center. However, it is still clear that some issues addressed in this field that are investigated in this paper raise concerns. It is proposed that future research be on efforts to put into investigation of how to manage a large population of students in a SACs, how to provide space and finances to develop the SACs within the role of the SAC managers, and how to deal with technological problems for students and staff on campus. The research blanks in regard to learning autonomy mean that there are great challenges ahead for future researchers in mainland China.

\section{REFERENCES}

[1] R. L. Allwright, Autonomy and individualization in whole-class instruction In Individualization and autonomy in language learning, edited by A. Brookes and P. Grundy, pp. 35-44. London: Modern English Publications and the British Council, 1988.

[2] S. Amber, "Motivating students through power and choice," English Journal, vol. 100, pp. 65-69, 2010.

[3] L. Barnett, "Teacher off: Computer technology, guidance and self-access," System, vol. 21, pp. 295-304, 1993.
[4] J. B. Biggs, "Western misperceptions of the Confucian-heritage learning culture," in The Chinese learner: Cultural, psychological and contextual influence, eds. D. A. Watkins \& J. B. Biggs. Hong Kong: CERC and ACER, 1996, pp. 45-67.

[5] D. Boud, "Toward student responsibility for learning," in Developing student autonomy in learning, ed. D. Boud. London: Kogan Page Ltd, 1981, pp. 21-24

[6] A. Brookes and P. Grundy, Individualization and autonomy in language learning, London: Modern English Publications, the British Council, 1988.

[7] J. Castellano, J. Mynard, and T. Rubesch, "Study technology use in a self-access center," Language learning \& Technology, vol. 15. no. 3 2011, pp. 12-27.

[8] N. Charge and L. B. Taylor, "Recent developments in IELTS," ELT Journal, vol. 51, no. 4. pp. 374-380, 1996.

[9] A. W. Chickering, Education and identity, San Francisco, Cal: Jossey-Bass, 1969

[10] M. Cortazzi and L. Jin, "English teaching and learning in China," Language Teaching, vol.29, no. 2, pp. 61-80, 1996.

[11] L. Dam, Learner autonomy Dublin: Authentick, 1995.

[12] D. F. Dearden, "Autonomy and education," Education and the development of reason, eds. D. F. Dearden, P. E. Hirst and R. S. Peters. London: Routledge and Kegan Paul, 1972, pp. 448-465.

[13] L. Dicksinson, Self-instruction in language learning, Cambridge: Cambridge University Press, 1987.

[14] A. Wenden and I. Rubin, Learner strategies in language learning, Hemel Hempstead: Prentice Hall, 1987.

[15] X. Yao, An introduction to Confucianism, Cambridge: Cambridge University Press, 2000.

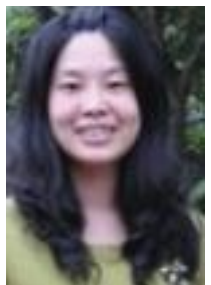

Jinjin Lu is a PhD student in Faculty of Education, University of Tasmania. She has worked as lecturer in Jimei University from 2006 to2012. At present, she is a PhD student in UTAS. Her research interest is in TESOL and language literacy. 